\title{
The Legal Protection of Development-Induced Displaced Persons in African
}

\author{
Romola Adeola \\ McGill University, Montreal, Qc \\ romola.adeola@mcgill.ca
}

\begin{abstract}
Development-induced displacement has become one of the pressing human rights concern in Africa with thousands displaced by development projects across the continent each year. The political viewpoint that development projects are panaceas for economic development has often made their socio-economic implications for displaced persons' pale in comparison.

In a bid to address this form of displacement, the African Union Convention for the Protection and Assistance of Internally Displaced Persons mandate states to prevent development-induced displacement. Seeking to mitigate the tension between the essence of the development project and respect for the rights of displaced persons, article 10 of the Convention mandate states to prevent development-induced displacement. This paper discusses the content of the obligation in fostering legal protection for development-induced displaced persons in Africa.
\end{abstract}

\section{Keywords}

development-induced displacement - IDP Convention - Internally Displaced Persons - internal displacement - Kampala Convention 
Development-induced displacement is a significant driver of internal displacement in Africa. ${ }^{1}$ While much of the emphasis on internal displacement has centered primarily on conflict, the issue of development-induced displacement has gained less prominence, however, its impacts in Africa date back to the early 1950 s. $^{2}$ Following independence, many African countries regarded development projects as a sure path for economic development and freedom. Development projects were considered essential panaceas in fostering growth and economically positioning Africa with the rest of the world and there were good reasons to believe this.

In 1944, a year prior to the end of the Second World War, an idea was conceived for the creation of international financial institutions to provide financial assistance for the reconstruction of European states that had been affected by the War. ${ }^{3}$ A conference was held in the United States of America in Bretton Woods, New Hampshire, which led to the creation of the International Bank for Reconstruction and Development and the International Monetary Fund. Following the establishment of these institutions, a Europe Recovery Programme was launched for the reconstruction of Western European states whose economy had been crippled by the Second World War.

1 R Adeola, "The right not to be arbitrarily displaced under the United Nations Guiding Principles on Internal Displacement' (2016) 16(1) African Human Rights Law Journal 83, 85.

2 In Zambia, the Kariba Dam built in the 1950 os led to the displacement of an estimated 57,000 individuals who belonged to the Gwembe-Tonga tribe. Not only was resettlement not carried out with due regard for members of the tribe, the process was flawed. The World Commission of Dams notes that people were handled like animals and packed into lorries to resettlement sites. Following resistance from members of the tribe, 8 persons were killed, while 32 were injured. In the 1970 s when the Cahora Bassa Dam was built in Mozambique, thousands of displaced individuals were improperly rehabilitated. Isaacman \& Sneddon notes that '[f] ood insecurity and hunger were ... an initial part of the displacement process. The choice of selection sites for those displaced was motivated by state security concerns rather than the need to improve the livelihood capacities of those displaced. See International Rivers, The World Bank's big dam legacy (International Rivers, California, 2007) 3; 'Kariba dam people still neglected - Chief Chipepo', Zambian Watchdog (17 May 2010); A Isaacman \& C Sneddon, 'Toward a social and environmental history of the building of Cahora Bassa dam' (2000) 26 Journal of Southern Africa Studies 618; World Commission of Dams, Kariba dam:Zambia and Zimbabwe (Cape Town, November 2000).

3 PW Preston, Development theory: an introduction (Oxford: Blackwell, 1996) 157; D RolandHolst \& F Tarp, 'New perspectives on Aid effectiveness' in B Tungodden et al (eds), Toward propoor policies: aid, institutions, and globalization (Washington DC: World Bank Publications, 2004) 44. 
The Marshall Plan was designed to provide loans to Western European states for a period of four years to enable them develop large-scale industries for enabling economic growth. In Western Europe, the Marshall Plan was a success as the financial aid to these states revamped their economies and led to growth which the decision-makers who laid the foundations of the postwar order had good warrant to be proud [of]. ${ }^{4}$ The success of this initiative validated the idea that large-scale development projects geared towards modernisation were significant in stimulating economic growth as they create an enabling environment. This modernisation approach was, at the time, expected to result in the union of political economies, significantly that of the West and East.

When African states began gaining independence in the 1950s, this modernisation approach was adopted as a developmental policy. African states conceived of development projects as essential springboards for economic development. In this period, dams for hydropower generation attained the most notoriety. Within the second half of the 2oth century, more than 1,00o dams were built in Africa with about 20 megaprojects in various parts of the continent. ${ }^{5}$ While displacement figures from these projects draw a significant concern, the impact of these projects on the livelihood capacities of those displaced is most worrisome. When the Kainji dam was constructed in Nigeria in the 1960s, over 40,000 people were displaced. Although resettlement was carried out, housing units provided did not adequately reflect the household sizes and the socio-cultural lifestyle of those displaced. When the Inga dams were built in the 1970s in the Democratic Republic of Congo, those displaced were promised compensation. However, for more than 40 years, the displaced persons have not been properly compensated. ${ }^{6}$ Yet a third Inga Dam is being proposed which is expected to displace about 35,000 people. ${ }^{7}$

In recent times, this rhetoric of elevating development projects above the livelihood capacities of displaced populations has significantly resonated in various parts of the continent. In Angola, around 3000 families were displaced

4 JB De Long and B Eichengreen, The Marshall Plan: history's most successful structural adjustment program (Centre for Economic Performance and Landeszentral bank Hamburg Conference on Post-World War II European Reconstruction, 5-7 September 1991).

5 'AF Isaacman \& BS Isaacman, Dams, displacement, and the delusion of development: Cahora Bassa and its legacies in Mozambique, 1965-2007 (2013) 8-9.

6 International Rivers Infrastructure for whom? A critique of the infrastructure strategies of the Group of 20 and the World Bank (California: International Rivers Publication, 2012) 13 available online at https://www.internationalrivers.org/sites/default/files/attached-files/infrastructure_for_whom_report.pdf (accessed 24 February 2017).

7 M Mwenda, 'Inga 3, the world's largest dam will displace tens of thousands in DR Congo' Lifegate 23 January 2017. 
to make way for an urban renewal project in 2010 'with only 700 tents distributed to provide temporary shelter for some families in Tchavola, where there was no basic sanitation and little access to electricity, food or blankets. ${ }^{8}$ In Kenya, more than 15,000 individuals were displaced in 2011 for the Wilson International Airport without adequate compensation; in Nigeria, 34,700 people were violently displaced in November 2016 and March 2017 from Otodo-Gbame community in Lagos without resettlement. ${ }^{9}$ Aside from state orchestrated displacement, businesses have also become visible actors in development-induced displacement narrative on the continent. In Uganda, for instance, the Bidco Oil Refineries displaced more than 100 farmers when it cut down trees on land belonging to these farmers for its palm oil plantation project around Lake Victoria in 2015 without adequate compensation. ${ }^{10}$ In Guinea, more than 1000 people were displaced to make way for the extension of an open pit mine by Anglo-Gold Ashanti in Kintinia - a village in the northeastern part of Guinea. ${ }^{11}$ Although there was resettlement, the process was flawed with anomalies. Villagers were left out of consultation processes in resettlement action plans and given compensation that was inadequate for livelihood recovery. ${ }^{12}$ Similar occurrences have resonated in Zambia, Mozambique and Ghana. ${ }^{13}$ Recognising the need to address this root cause of

8 SR Akinola, 'Urbanization, collective action and coping strategies in informal areas of African cities: a polycentric environmental planning perspective' in S Attia et al Dynamics and resilience of informal areas: international perspectives (Cham: Springer, 2016) 12.

R Adeola, 'What does development-induced displacement look like in Africa?', Internal Displacement Monitoring Centre (Geneva, 7 December2016); L Gottbrath 'Thousands displaced as police raze Lagos Otodo Gbame' Al Jazeera 10 April 2017; Y Kazeem, 'Lagos is doubling down on kicking out thousands of' waterfront slum dwellers' Quartz Africa 11 April 2017.

10 L Ochieng 'Ugandan farmers want to cut ties with Bidco' Daily Nation 23 February 2016; Bugala Farming Association 'Bidco v Uganda's farmers - who do you believe?' Globe Newswire 25 February 2016.

11 'Guinea: South Africa's AngloGold Ashanti accused of wrongful eviction of villagers' West Africa Democracy Radio 2 February 2017 https://soundcloud.com/westafricademocracyradio/guinea-south-africas-anglogold-ashanti-accused-of-wrongful-eviction-of-villagers (accessed 24 February 2016); Advocates for Community Alternatives and Communities First 'Involuntary resettlement for the extension of a gold mine in Kintinian: Kintinian, Guinea - fact-finding mission report' January 2017 https://communitiesfirst.net/wp -content/uploads/2017/01/CECIDE-MDT-Report-\%E2\%80\%93-Kintinian-ResettlementAngloGold-Ashanti-Jan-2017.pdf (accessed 24 February 2017).

12 Advocates for Community Alternatives and Communities First (n 13 above).

13 In Zambia, more than 2,00o farmers were displaced for cement manufacturing by Dangote in 2011 with 250 dollars offered as compensation for each hectare. In Mozambique over 
internal displacement, article 10 of the Kampala Convention mandate states to 'as much as possible' prevent displacement caused by projects carried out by public and private actors. ${ }^{14}$ While this provision seeks to prevent developmentinduced displacement, the IDP Convention does not set a yardstick for what 'as much as possible' entails. Referring to international law, this paper advances normative clarity on the content of this provision in the protection of development-induced displaced persons.

\section{$2 \quad$ Norm}

In article 4(4), the Kampala Convention recognises the right of all persons to be prevented against arbitrary displacement. ${ }^{15}$ While the Kampala Convention does not explicitly prohibit internal displacement, it subjects the form of displacement to the test of arbitrariness. In the section on definition, arbitrary displacement is not described. However, the Kampala Convention refers to the grounds listed in article 4(4)(a) to (h) as a reference point for assessing the arbitrariness of a given form of displacement. In this provision, there are two kinds of displacements. Those are out-rightly non-permissible and as such may not be subjected to the test of arbitrariness. These includes displacement due to racial, ethnic or religious affiliations and harmful practices-induced displacement. ${ }^{16}$ Other non-permissible grounds are the use of displacement as collective punishment and displacement in furtherance of an international

2000 families were displaced in the Tete region for Rio Tinto and Vale between 2009 and 2014. Aside from the concern that arable resettlement land was insufficient, these lands were also unsuitable to produce staple crops. In Ghana, those displaced to make way for the Ghanaian Australian Goldfields Mining Project (GAGMP) were not properly consulted nor compensated. Nana Kofi Karikari \& 44 others $v$ Ghanaian Australian Goldfields (GAG) Ltd (2007) Suit No LS.34/97; M Lopes 'Miners Vale, Rio Tinto accused of neglecting displaced Mozambicans' Reuters 23 May 2013; Human Rights Watch, 'What is a house without food?' Mozambique's coal mining boom and resettlements (2013); Oxfam Mining, resettlement and lost livelihoods: listening to the voices of resettled communities in Mualadzi, Mozambique (2015); African Centre for Biodiversity, Which way forward for Zambia's smallholder farmers: Green Revolution input subsidies or agro-ecology (Johannesburg: African Centre for Biodiversity, 2015), 22.

14 African Union Convention for the Protection and Assistance of Internally Displaced Persons in Africa, adopted at the Special Summit of the African Union Heads of States and Government in Kampala, Uganda (19-23 October 2009) (Kampala Convention).

15 Kampala Convention (n 14) art 4(4).

16 Kampala Convention (n 14) art 4(4)(a). 
crime. ${ }^{17}$ In the second category, displacement due to armed conflict and natural disasters may occur only when they fulfil certain conditions. In situations of natural disaster, displacement may only occur where it is for the 'safety and health of those affected.18 In the case of armed conflict, displacement may only occur where it is for the protection of civilians or military exigency ${ }^{19}$ In either circumstance, it is imperative that international humanitarian law, specifically the Fourth Geneva Convention, is applied in the treatment of the displaced persons. ${ }^{20}$

However, in respect of development projects, article 4(4) of the Kampala Convention is silent. Only in article 10 of the Kampala Convention is an insight advanced. However, the provision of article 10 sets a vague standard for understanding what constitutes arbitrariness in development-induced displacement situations. Under article 10(1), states are 'as much as possible' required to prevent development-induced displacement. ${ }^{21}$ Adopting a literal interpretation, what states are required to do is prevent development-induced displacement to the greatest measure possible. However, what amounts to the greatest measure possible is unclear and only shrouds the content of this provision in ambiguity. But considering that a key objective of the Convention is to 'prevent or mitigate, prohibit and eliminate root causes of internal displacement as well as provide for durable solutions, ${ }^{\prime 2}$ a literal interpretation is inadequate in construing what amounts to arbitrariness in situations of development-induced displacement. Adopting a teleological approach, it is relevant to consider the notion of 'arbitrariness' in international law in constructing normative clarification that aligns with the treaty's emphasis on respect for international law. In clarifying this notion, the decision of the International Court of Justice (ICJ) in the ELSI case is relevant. ${ }^{23}$

In this case, the ICJ had to determine whether the act of Italy in preventing two American corporations from liquidating their assets in their Italian subsidiary was an arbitrary exercise of power in violation of a treaty agreement

\footnotetext{
17 Kampala Convention (n 14) art 4(4)(g) and 4(6).

18 Kampala Convention (n 14) art 4(4)(f).

19 Kampala Convention (n 14) art 4(4)(b).

20 The Geneva Convention Relative to the Protection of Civilian Persons in Time of War (12 August 1949).

21 Kampala Convention (n 14) art 10(1).

22 Kampala Convention (n 14) art 2(a).

23 Case concerning Elettronica Sicula S.p.A (ELSI) (United States of America $v$ Italy) ICJ (20 November 1950) (1950) ICJ General List No 76 (ELSI case).
} 
between the United States and Italy. ${ }^{24}$ In the judgement, the ICJ clarified that there is a distinction between the legality of an act and its arbitrariness ${ }^{25}$ and as such to subject a test of arbitrariness to the question of lawfulness of such act was 'to deprive it of any useful meaning in its own right.'26 The ICJ stated that the arbitrariness of an act is 'not so much something opposed to $a$ rule of law' rather it is 'something opposed to the rule of law'. ${ }^{27}$ The ICJ's choice of semantics stresses the point that the arbitrariness of an act relates to legality of process. This is made clear in the subsequent dictum of the ICJ that what arbitrariness entails is a 'willful disregard for the due process of law'.28

Thus, an inquiry into the arbitrariness of an act involves a determination of its due process requirements. By incorporating the notion of 'arbitrariness'

24 Ibid.; see also Peter D Trooboff 'Elettronica Sicula S.p.A. (ELSI) (United States v Italy). 1989 ICJ Rep. 15, 28 ILM 1109 (1989)' (1990) 84(1) American Journal of International Law 249-258.

25 Within the context of development-induced displacement, the question of lawfulness raises an inquiry into the legitimacy of the displacement for the development imperative. In the main, this is a question the Kampala Convention answers in not setting an absolute prohibition on development-induced displacement. However, what the Kampala Convention prohibits is arbitrariness, which beyond the question of lawfulness, raises an inquiry into the compliance with the procedural elements of interference with rights or interests. In the ELSI case, the ICJ emphasised that the discovery 'that an act was unlawful may well be relevant to an argument that it was also arbitrary; but by itself, and without more, unlawfulness cannot be said to amount to arbitrariness.' See ELSI case (n 23) para 124; See also Azurix Corp. v The Argentine Republic ICSID Case No. ARB/01/12 (Annulment Proceedings) (1 September 2009) paras 144-145.

$26 \quad$ ELSI case (n 23) para 124.

$27 \quad$ ELSI case (n 23) para 128.

28 Ibid. A willful disregard for legal due process contemplates two things. First is the existence of legal procedural steps that are to be followed. Second, is a failure to comply with these procedural steps 'the observance of which is indispensable to the proper administration of justice.' The absence of intent or wilfulness will not vindicate a failure to comply with a due process of law since an act will only qualify as a disregard where it is not as a 'result of reasoned judgment', the existence of which will of necessity imply knowledge of the procedural requirements. See DD Nsereko 'Arbitrary deprivation of life: controls on permissible deprivations' in BG Ramacharan (ed) The right to life in international law (Dordrecht: Martinus Nijhoff Publishers, 1985) 245, 248; LG\&E Energy Corp., $L G \& E$ Capital Corp. and LG\&E International Inc. $v$ Argentine Republic ICsID Case No ARB/02/1 (Decision on Liability) (3 October 2006) para 162; Sempra Energy Internationalv The Argentine Republic, ICSID Case No. ARB/02/16 (Award) (28 September 2007) para 318; Enron Corporation and Ponderas Assets, LPv Argentine Republic, ICSID Case No. ARB/01/3 (22 May 2007) (Award) para 281; CH Schreuer 'Protection against arbitrary or discriminatory measures' in CA Rogers and RP Alford (eds), The future of investment arbitration (Oxford: Oxford University Press, 2009) 183, 188. 
in the contextual interpretation of its text, the Kampala Convention seeks to strike a balance between the development imperative and the protection of development-induced displaced persons. In achieving this, there are three procedural requirements. First, states must conduct prior-impact assessments. Second, there must be consultation with persons likely to be displaced. Third, there must be a consideration of feasible alternatives to the development project. These three procedures are considered in turn.

\subsection{Prior-impact Assessments}

There are three pertinent reasons why an assessment of prior impacts of projects are essential. These reasons will be discussed with due reference to three development projects. In 2009, the government of River State in Nigeria unveiled an infrastructural development project themed Greater Port Harcourt City Development. ${ }^{29}$ The essence of this project was to 'transform the Greater Port Harcourt Area into a world class city, internationally recognised for excellence, and the preferred destination for investors and tourism. ${ }^{30}$ For the implementation of the project, waterfront areas in the state were to be transformed in line with the developmental agenda of promoting tourism and facilitating first-rate infrastructure. Consequently, waterfront communities were to be displaced. In 2009, 17,000 people were displaced from the Njemanze water-front community without compensation or adequate shelter. ${ }^{31}$ While the imperative of the project was considered, the impacts on the livelihood sustenance on displaced persons were not assessed. As such, there were no prospective basis on which to manage the project impact on the capacities of displaced persons. As with the Greater Port Harcourt City Development Project, the construction of the Merowe Dam in Sudan which displaced more than 50,00o people was done without clear impact assessments. ${ }^{32}$ Accordingly, protests - which could have been avoided through proper impact assessments - have occurred in view of the dire impacts. ${ }^{33}$ In 2004, when Chinese mining company began extracting chrome in the Tengenenge community in the northern region of Guruve in

29 Greater Port Harcourt City Development Authority 'The Authority' http://www.gphcity. com/about/authority.php\# (accessed 28 February 2017).

$30 \quad$ Ibid.

31 'Nigeria: Two years after Njemanze community was demolished - Nigerians need a housing policy that respects human rights' (Amnesty International Joint Public Statement, 26 August 2011, AFR 44/020/2011).

32 R Abass 'Sudan: no clear studies on impacts of Merowe dam' Inter Press Service 2 January 2012.

33 International Rivers 'Merowe Dam, Sudan' https://www.internationalrivers.org/ campaigns/merowe-dam-sudan-o (accessed 28 February 2017). 
Zimbabwe, no environmental impact assessment (EIA) was conducted prior to the project. As the company had no environmental projection of its impact, its mining site was constructed close to a dam from which community members sourced water. ${ }^{34}$ The failure to carry out EIA and develop an environmental strategy led to pollution and death of livestock belonging to members of the local communities.

From the foregoing, it is deducible that prior impact assessments are essential for the development of project action plans; avoidance of conflict; and consideration of alternatives to project or location. In the Port Harcourt City project, livelihood reconstruction for the waterfront community could have been managed through the consideration of project impacts. Similarly, in the case of the Merowe Dam, protests could have been avoided had there been assessments taking into cognisance the project's direct impact on the local communities and indirect impacts on downstream communities. In the northern Zimbabwe case, an impact assessment would have called for a consideration of the project design and location alternatives.

Article 10(3) of the Kampala Convention incorporates this procedural step in requiring states to conduct socio-economic and environmental impact assessments prior to the implementation of development projects. As the aim of the prior impact assessment is to foster sustainable development and ensure proper rehabilitation for project-affected persons, it must be participatory. As such, the due process requirement of article 10(2) must be met. The next section discusses this requirement.

\subsection{Consultation}

Article 10(2) of the Kampala Convention require states to ensure that persons likely to be displaced are duly informed and consulted prior to the implementation of the development project. In development practice, consultation is considered a passive level of participation. While it is beyond information (which does not consider the views of stakeholders), it is not control..$^{35}$ There is also a limit to stakeholder involvement. For instance, in consultation, stakeholders can only express views which may be considered in the decision-making process. However, stakeholders are not involved in decision-making. An example of consultation resonates from the Sabodala Gold Mine case. In 2010, families from Dambankhoto village who were to be moved in the Sabodala gold mining

\footnotetext{
34 G Makore and V Zano, Mining within Zimbabwe's Great Dyke: extent, impacts and opportunities (Zimbabwe Environmental Law Association, 2012) 16.

35 See SR Arnstein 'A ladder of citizen's participation' (1969) 35(4) Journal of the American Institute of Planners 216.
} 
region to make way for a tailing waste dam had limited negotiating powers as their land were occupied prior to the conclusion of agreements. Though they were consulted, the consultation process did not significantly impact on the resettlement action plan as the facilities they found at the site 'were not what they had been promised. ${ }^{36}$ Some of the housing units had also not been completed prior to displacement as against what the affected communities had been assured. This tokenistic approach does not reflect the notion of participation in development from a rights-based perspective. The human rights-based approach to development requires participation to be meaningful and geared towards empowerment. Under international human rights law, there are no hierarchical distinctions in participation. The focus of participatory processes in development planning, activities and projects must be the realisation of social, economic and cultural development for the stakeholders involved. In the development-induced displacement context, a rights-based consultative approach must seek to empower displaced persons towards the reconstruction of their livelihood capacities. However, the objective is not achievable where consultation is a view gathering process. A relevant question, which therefore resonates, is how should consultation be understood within the context of article 10(2) of the Kampala Convention?

Drawing on the notion of consultation in African traditional systems, consultation must be a consensus building process. Among the Akans of Ghana, this tradition is evinced in proverbs that 'one head does not go into council'. ${ }^{37}$ In the Kgotla - a traditional institution recognised in Botswana as a local level of governance, decisions are reached through a consensus building process. $^{38}$ Similar practices resonate among the Borana people in Ethiopia and Maasai in Kenya. ${ }^{39}$ With this strong emphasis on consensus resonating from African societies, consultation of local communities across the continent cannot be conceived merely as a process of legitimising ready-made decisions. The emphasis must be on consensual decision-making and as such the

36 Amnesty International Mining and human rights protection in Senegal: closing the gaps in protection (2014) 17 .

37 SJ Salm \& T Falola Culture and customs of Ghana (2002) 61.

38 KB Dipholo, N Tshishonga and E Mafema, 'Traditional leadership in Botswana: opportunities and challenges for enhancing good governance and local development' (2014) 3(2) Journal of African and Asian Local Government Studies 17; KC Sharma 'Role of traditional structures in local governance for local development: the case of Botswana' (Paper for the Community Empowerment \& Social Inclusion Programme, World Bank Institute).

39 J Markakis Ethiopia: the last two frontiers (Suffolk: Boydell \& Brewer, 2011) 67; E Mwangi and E Ostrom 'Top-down solutions: looking up from East Africa's rangelands' (2009) 51(1) Environment: Science and Policy for Sustainable Development 34, 40. 
consultative process must be geared towards securing the agreement of persons likely to be displaced. In actualising this objective, a useful tool in the international human rights law is the well-developed notion of free, prior and informed consent (FPIC). Developed from the narrative on the protection of indigenous peoples, ${ }^{\prime 0}$ the doctrine of FPIC has been normatively extended to non-indigenous communities. For instance, in the Ecowas Directive on the Harmonisation of Guiding Principles and Policies in the Mining Sector, businesses are mandated to 'obtain free, prior, and informed consent of local communities' before the commencement of mining operations ${ }^{41}$ In the context of internal displacement, the United Nations Guiding Principles on Internal Displacement requires that the 'free and informed consent of those to be displaced shall be sought'.42 While the obligation does not extend to obtaining consent, it is important for development actors to begin from this premise to ensure that displaced persons have a sense of ownership of the consultative process and to foster sustainable development.

\subsection{Feasible Alternatives}

A third key imperative in the prevention of arbitrary development-induced displacement is the consideration of feasible alternatives to the development project. The pertinence of this requirement resonates from the need for displacement to occur as a last resort. ${ }^{43}$ As such, states should foster means that are less intrusive of rights in the realisation of development projects.

40 See United Nations Declaration on the Rights of Indigenous Peoples, adopted by United Nations General Assembly Resolution 61/295 (13 September 2007); UN Human Rights Council 'Extractive industries and indigenous peoples,' Report of the Special Rapporteur on the rights of indigenous peoples, Prof James Anaya, submitted pursuant to UN Human Rights Council resolution 6/12 and 15/14, 1 July 2013, UN Doc. A/HRC/24/41 (1 July 2013) (UN Extractive Industries Report); UN collaborative initiative on Reducing Emissions from Deforestation and forest Degradation Programme Guidelines on Free, Prior and Informed Consent (2013).

41 ECOWAS Directive on the Harmonization of Guiding Principles and Policies in the Mining Sector of 27 May 2009, art 16(3).

42 UN Commission on Human Rights, Addendum, 'Guiding Principles on Internal Displacement' Report of the Representative of the Secretary-General, Mr. Francis M. Deng, submitted pursuant to Commission on Human Rights resolution 1997/39, UN Doc. E/ CN.4/1998/53/Add.2 (11 February 1998) (the Guiding Principles), art 7(2)(c).

43 Resolution on the right to Adequate Housing and Protection from Forced Evictions, adopted at the 52nd Ordinary Session of the African Commission on Human and Peoples' Rights held in Yamoussoukro, Côte d'Ivoire (9-22 October 2012) in Christof Heyns and Magnus Killander Compendium on key human rights documents of the African Union (2013, Pretoria University Law Press) at $442-443$. 
While this procedure resonates in article 10(2), the Kampala Convention does not offer guidance on what these alternatives should entail. This article argues for six alternatives.

The first is the 'no-action' alternative. ${ }^{44}$ As development projects often occasion displacement of local communities and create livelihood challenges for those displaced, the option of not implementing these projects at all should be given due consideration by states. This is important, in part, due to some of the evidence that abound in respect of development projects failing to meet the objective necessitating their creation. For instance, the Inga Dams I and II in the DRC have failed to fully address hydropower generation concerns. ${ }^{45}$ However, given that the obligation on states to prevent developmentinduced displacement is not absolute the no-action alternative may not always be implemented.

A second alternative to consider is the implementation of the development project in a location where displacement is unlikely to occur. While this alternative may not be feasible for urban renewal projects; for large-scale agricultural investment, this alternative may be an option. However, where this alternative is not feasible, development actors should consider the possibility of collaborative project implementation with the local communities. A collaborative project implementation approach is relevant in situations where displacement of indigenous peoples is likely to occur. The need for development actors to consider this approach resonates in article 4(5) of the Kampala Convention, which requires states to ensure protection of communities with special attachment to land. ${ }^{46}$ In the case of the San peoples in the Central Kalahari Game Reserve, such collaborative approach for wildlife conservation will have been a viable alternative to displacement due in part to the fact that the San indigenous peoples have a rich traditional knowledge of conserving the flora and fauna. ${ }^{47}$

44 Organisation for Economic Cooperation and Development 'Guidelines for aid agencies on involuntary displacement and resettlement in development projects' (1992) (OECD Guidelines) 6.

45 P Bosshard 'How the Inga dams are holding the Congo's energy future hostage' Huffington Post 10 June 2015 .

46 Kampala Convention (n 14) art 4(5).

47 Government reports indicate that 'between 1986 and 1996 [prior to the forced resettlement of the San] "wildlife biomass more than doubled" in the CKGR.' See 'Botswana: culture under threat - special report on the San Bushmen (I)' IRIN 5 March 2004. 
However, where this alternative is not feasible, it is imperative to consider strategies aimed at minimalising displacement. ${ }^{48}$ Closely linked to this alternative is the fifth alternative of considering alterations to project designs. The emphasis of this strategy is on likely options to realising a development objective. For instance, if an objective is to generate hydropower, alternative project designs will involve considering solar or wind energy where either of these can be harnessed without occasioning displacement.

But where an alternative project design is not feasible, a sixth alternative to consider is the negotiation of lease agreements with local communities to avoid displacement. An example of this was in the case of the Jintsu Gawa Dam in Japan in the 1950s. ${ }^{49}$ The Japanese government entered a lease with peasant landowners rather than taking over their land. ${ }^{50}$

However, where the various alternatives are not feasible, involuntary displacement may occur subject to the provision of fair and just compensation in line with article $12(1)$ of the Kampala Convention. ${ }^{51}$ It is imperative for states to ensure that local communities are trained in income-generating projects that are agreed upon to avoid impoverishments.

\section{Conclusion}

In seeking to prevent arbitrary development-induced displacement, article 10 of the Kampala Convention emphasises the need for a balance to be struck between the imperative of development and the protection of persons likely to be displaced. This paper argues that there are three key due process requirements that must be met in avoiding arbitrary displacement. First, prior-impact assessments must be carried out prior to the implementation of the development project. Second, persons likely to be displaced must be duly consulted. Third, feasible alternatives to the development project must be explored with

48 Principle 32 of the Kothari Principles lends credence to this alternative. See UN Human Rights Council, 'Basic principles and guidelines on development-based evictions and displacement,' Report of the Special Rapporteur on adequate housing as a component of the right to an adequate standard of living, Mr Miloon Kothari Un Doc A/HRC/4/18 annex I (5 February 2007).

49 MM Cernea, 'Compensation and investment in resettlement: theory, practice, pitfalls, and needed policy reform' in Michael M Cernea and Hari M Mathur (eds), Can compensation prevent impoverishment? Reforming resettlement through investments and benefit-sharing (Oxford: Oxford University Press, 2008) 78.

5o Ibid.

$5^{1} \quad$ Kampala Convention (n 14) art 12(1). 
persons likely to be displaced. As at May 2017, 26 member states of the African Union had ratified the Kampala Convention. While the Kampala Convention emphasises regional cooperation, the ultimate test of its significance in providing durable solutions to internal displacement is at the domestic level. As such, states must ensure that normative and institutional reforms are made in realising the obligation in the Kampala Convention. 